Barrios to Burbs 



\section{Barrios to Burbs}

The Making of the Mexican American Middle Class

Jody Agius Vallejo 
Stanford University Press

Stanford, California

(이리 by the Board of Trustees of the Leland Stanford Junior University. All rights reserved.

No part of this book may be reproduced or transmitted in any form or by any means, electronic or mechanical, including photocopying and recording, or in any information storage or retrieval system without the prior written permission of Stanford University Press.

Printed in the United States of America on acid-free, archival-quality paper.

Library of Congress Cataloging-in-Publication Data

Agius Vallejo, Jody, author.

Barrios to burbs : the making of the Mexican-American middle class / Jody Agius Vallejo. pages $\mathrm{cm}$

Includes bibliographical references and index.

ISBN 978-0-8047-8139-8 (cloth : alk. paper)

1. Middle class Mexican Americans. 2. Mexican Americans-Social conditions.

3. Social mobility-United States. I. Title.

E184.M5A64 2012

973.046872-dc23

2012004369

Typeset by Westchester Book Group in 10/14 Minion 
For Johnny, with love and gratitude 
